\title{
ANALISIS KANDUNGAN LOGAM BERAT TIMBAL (Pb) Dan KADMIUM (Cd) PADA UDANG WINDU (Penaeus monodon) DI PERAIRAN BENIUNG TARAKAN KALIMANTAN TIMUR DENGAN METODE SPEKTROFOTOMETRI SERAPAN ATOM
}

\author{
Rais Razak, Siti Masyitah \\ Fakultas Farmasi Universitas Muslim Inodnesia \\ Email : jelek.qu.rr@gmail.com
}

\begin{abstract}
The research have done to analysis of metal weigth lead $(\mathrm{Pb})$ and Cadmium (Cd) at Windu Prawn (Penaeus monodon) in Beniung territorial water Tarakan East Kalimantan by Atomic Absorbtion Spectrophotometry (SSA). The research enwrap qualitative and quantitative analysis. Before to be analised, first to do destruction of Windu Prawn (Penaeus monodon) later on disolved in $\mathrm{HNO}_{3}$ and $\mathrm{HCl}$. Qualitative analysis used reactant specific and quantitative analysis used atomic absorbtion spectrophotometry (SSA) at wave length of 217,0 $\mathrm{nm}$ and 228,8 $\mathrm{nm}$ for lead and cadmium respectively. Result of research find average rates of $\mathrm{Pb}$ metal and cadmium letal in Beniung territorial water Tarakan East Kalimantan is 0,7636 ppm and is 0,4730 ppm. From result of research to showing that average rates $\mathrm{Pb}$ and $\mathrm{Cd}$ metal to Beniung territorial water Tarakan East Kalimantan, it is not over from sill limit and according to DIRJEN POM regulation.
\end{abstract}

Key Words : Analysis, $\mathrm{Pb}, \mathrm{Cd}$, Penaeus monodon, Atomic Absorbtion Spectrophotometry

\section{PENDAHULUAN}

Logam berat masih termasuk golongan logam dengan kriteriakriteria yang sama dengan logamlogam lain. Perbedaannya terletak dari pengaruh yang dihasilkan bila logam berat ini berikatan dan atau masuk ke dalam tubuh organisme hidup. Sebagai contoh, adalah logam Kadmium (Cd), pencemaran yang disebabkan oleh buangan industri yang mengandung unsur dan atau persenyawaan dari logam kadmium ini, telah mengakibatkan timbulnya penyakit mental dan kelainan syaraf pada penduduk yang hidup di sekitar Teluk Minamata di Jepang. Toksisitas yang dikandung oleh logam kadmium tersebut juga mengakibatkan terjadinya kerapuhan pada tulang penderita (Palar, 2008).

Contoh lain adalah logam Timbal (Pb), juga merupakan zat yang terbukti mampu menekan sistem imun 
sehingga terjadi penurunan jumlah sel penghasil antibodi. Fungsi sistem imun adalah mengenali dan memusnahkan agens yang berbahaya, maka jika sistem imun tidak berfungsi dengan baik, hal itu akan memperbesar kerentanan tubuh terhadap bakteri, parasit, dan virus serta kerentanan terhadap kanker (Widyastuti, 2006).

Sebagian besar penduduk Tarakan bermata pencaharian sebagai nelayan dengan membudidayakan udang windu pada tambak-tambak yang sengaja dibuat bersambungan langsung dengan laut. Budidaya Udang Windu ini sebagian di jual dan sebagiannya lagi di konsumsi sebagai lauk. Akan tetapi perairan laut Tarakan yang tercemar tentu saja akan memberi pengaruh dan dampak pada keadaan biota di dalamnya (Massofa, 2008).

\section{METODE PENELITIAN}

\section{A. Alat dan Bahan}

Alat-alat yang digunakan pada penelitian ini adalah : Batang pengaduk (Normax), Cawan porselin, Corong gelas, Erlenmeyer (pyrex), Gelas kimia (Pyrex), Gelas ukur (Pyrex), Hot plate, Kertas saring, Labu Tentukur (Pyrex), Neraca analitik (Kren 770), Oven (Gallenkamp), Pipet volume (Brand), Pipet tetes (Pyrex), Rak tabung, Spektrofotometri Serapan Atom (Varian AA 6200), Tanur (Furnace), Tabung reaksi (Pyrex), Timbangan analitik (Chyo).

\section{B. Prosedur Penelitian}

\section{Pengambilan sampel}

Sampel yang dianalisis dalam penelitian ini adalah udang windu (Penaeus monodon) asal perairan Beniung Tarakan Kalimantan Timur.

\section{Pengolahan sampel}

Udang windu yang telah diperoleh dibersihkan dengan air mengalir kemudian dipotongpotong lalu dikeringkan dan dihaluskan.

\section{Penyiapan Larutan Sampel}

a. Ditimbang dengan teliti 10 gram sampel dalam cawan porselen kemudian didekstruksi dengan cara diabukan selama 4-5 jam pada suhu $550^{\circ} \mathrm{C}$ dalam tanur dan dibiarkan dingin dalam eksikator

b. Abu ditambahkan dengan 5 $\mathrm{ml} \mathrm{HNO}_{3}$ kemudian kelebihan $\mathrm{HNO}_{3}$ diuapkan pada suhu $100 \div-200 \circ \mathrm{C}$ diatas penangas listrik. Kemudian cawan porselen yang berisi sampel 
dimasukan kembali ke dalam tanur dan dektruksi selama 1 jam pada suhu $550^{\circ} \mathrm{C}$ lalu didinginkan.

c. Abu dilarutkan dalam $5 \mathrm{ml}$ $\mathrm{HCl} 6 \mathrm{~N}$ kemudian disaring dengan menggunakan kertas saring Whatman ke dalam labu tentukur $50 \mathrm{ml}$ lalu dicukupkan volumenya hingga batas tanda menggunakan air suling.

d. Larutan sampel kemudian digunakan untuk uji kualitatif dan uji kuantitatif Timbal $(\mathrm{Pb})$ dan Kadmium (Cd).

4. Analisis Kualitatif Kandungan logam Timbal $(\mathrm{Pb})$.

a. Ke dalam tabung reaksi dimasukkan larutan sampel kemudian diteteskan kalium iodida, sehingga terbentuk endapan kuning setelah mendingin.

b. Ke dalam tabung reaksi dimasukkan larutan sampel kemudian diteteskan Natrium karbonat, sehingga terbentuk endapan putih, jika di didihkan tidak akan terjadi perubahan.

5. Analisis Kualitatif Kandungan logam Kadmium a. Ke dalam tabung reaksi dimasukkan larutan sampel kemudian diteteskan hydrogen sulfida, hasil positif bila tidak terbentuk endapan.

b. Ke dalam tabung reaksi dimasukkan larutan sampel kemudian diteteskan Natrium Hidroksida, sehingga terbentuk endapan putih.

6. Analisis

Kuantitatif

Kandungan Timbal secara SSA

a. Pembuatan larutan induk $\mathrm{Pb} 1000$ bpj

Ditimbang dengan teliti 0,1595 gram $\mathrm{Pb}\left(\mathrm{NO}_{3}\right)_{2}$, kemudian dimasukkan ke dalam labu ukur 100,0ml. Ditambah $2 \mathrm{ml}$ aquades, bila perlu dipanaskan pelanpelan, kemudian diencerkan dalam labu ukur sampai tepat tanda batas.

b. Pembuatan larutan baku $\mathrm{Pb}$

Dipipet $\quad 2,5 \mathrm{ml} \quad \mathrm{Pb}$ 1000 bpj (larutan induk) ke dalam labu ukur $25 \mathrm{ml}$, add sampai tepat tanda batas. Didapat baku Pb 100 bpj. Dipipet 2,5 ml Pb 100 bpj ke 
dalam labu ukur 25ml, add sampai tepat tanda batas.

Didapat baku Pb 10 bpj.

\section{Membuat larutan standar}

Dengan

menggunakan buret mikro, dipipet masing-masing $0,25 \mathrm{ml}, 0,5 \mathrm{ml}, 0,75 \mathrm{ml}, 1 \mathrm{ml}$, dan $1,25 \mathrm{ml}$ dari larutan baku $\mathrm{Pb} 10$ bpj ke dalam labu ukur 25ml, kemudian diadd sampai tepat tanda batas. Maka diperoleh larutan standar dengan konsentrasi $\mathrm{Pb}$ 0,1 bpj, 0,2 bpj, 0,3 bpj, 0,4 bpj, dan 0,5 bpj.

d. Pengukuran logam $\mathrm{Pb}$ dengan SSA

1) Alat spektrofotometri serapan atom diatur pada panjang gelombang 217,0nm, arus lampu $5,0 \mathrm{~mA}$, lebar celah (slit) $1,0 \mathrm{~nm}$.

2) Kedalam nyala udara asetilen diaspirasikan air dan alat pengukur dijadikan nol.

3) Secara berturut-turut diaspirasikan larutan baku menurut bertambahnya konsentrasi
4) Nilai absorban larutan baku dicatat

5) Larutan contoh kemudian diaspirasikan ke dalam nyala yang sebelumnya telah diaspirasikan dengan air suling untuk me-nolkan alat

6) Dibuat persamaan garis regresi linier dari absorban hasil pengukuran standar

7) Absorban hasil pengukuran contoh dimasukkan ke dalam persamaan regresi linier sehingga diperoleh konsentrasi contoh

7. Analisis Kuantitatif Kadar Kadmium (Cd) dengan SSA

a. Pembuatan larutan induk Cd 1000 bpj

$\begin{array}{rrr} & \text { Ditimbang } & \text { dengan } \\ \text { teliti } \quad 0,1792 & \text { gram }\end{array}$ $\mathrm{CdCl}_{2} \cdot \mathrm{H}_{2} \mathrm{O}$, kemudian dimasukkan ke dalam labu ukur 1000ml. Ditambah $2 \mathrm{ml}$ aquades, bila perlu dipanaskan pelan-pelan, kemudian diencerkan dalam labu ukur sampai tepat tanda batas.

b. Pembuatan larutan baku Cd 
Dipipet 2,5ml Cd 1000 bpj (larutan induk) ke dalam labu ukur $25 \mathrm{ml}$, add sampai tepat tanda batas. Didapat baku Cd 100 bpj. Dipipet 2,5 ml Cd 100 bpj ke dalam labu ukur $25 \mathrm{ml}$, add sampai tepat tanda batas. Didapat baku Cd 10 bpj.

\section{c. Membuat larutan standar}

\section{Dengan}

menggunakan buret mikro, dipipet masing-masing $0,25 \mathrm{ml}, 0,5 \mathrm{ml}, 0,75 \mathrm{ml}, 1 \mathrm{ml}$, dan $1,25 \mathrm{ml}$ dari larutan baku
Cd 10 bpj ke dalam labu ukur $25 \mathrm{ml}$, kemudian diadd sampai tepat tanda batas. Maka diperoleh larutan standar dengan konsentrasi Cd 0,1 bpj, 0,2 bpj, 0,3 bpj, 0,4 bpj, dan 0,5 bpj.

\section{d. Pengukuran logam Cd}

Alat spektrofotometri serapan atom di atur pada panjang gelombang 228,8 $\mathrm{nm}$, arus lampu 4,0 mA, lebar celah (slit) $0,5 \mathrm{~nm}$. Prosedur di ulangi seperti pada pengukuran logam $\mathrm{Pb}$

\section{HASIL PENELITIAN}

Tabel 1. Hasil analisis kualitatif timbal $(\mathrm{Pb})$ dan kadmium ( $\mathrm{Cd}$ ) pada udang windu (Penaeus monodon) dengan menggunakan pereaksi kimia

\begin{tabular}{|c|c|c|c|c|}
\hline \multirow{2}{*}{ Logam } & \multirow{2}{*}{ Pereaksi Kimia } & \multicolumn{2}{|c|}{ Hasil Reaksi } & \multirow{2}{*}{ Ket } \\
\hline & & Sampel & Pustaka & \\
\hline $\mathrm{Pb}$ & $\begin{array}{l}\text { Kalium iodida } \\
\text { Natrium karbonat }\end{array}$ & $\begin{array}{l}\downarrow \text { Kuning } \\
\downarrow \text { Putih }\end{array}$ & $\begin{array}{c}\downarrow \\
\downarrow \\
\downarrow\end{array}$ & $\begin{array}{l}+ \\
+\end{array}$ \\
\hline $\mathrm{Cd}$ & $\begin{array}{l}\text { Hidrogen sulfida } \\
\text { Natrium hidroksida }\end{array}$ & $\begin{array}{l}\downarrow \text { Kuning } \\
\downarrow \text { Putih }\end{array}$ & $\begin{array}{c}\downarrow \\
\downarrow \quad \text { Kuning } \\
\\
\quad \text { Putih }\end{array}$ & $\begin{array}{l}+ \\
+\end{array}$ \\
\hline
\end{tabular}

Keterangan :

$(+) \quad$ : Positif mengandung logam

( $\downarrow$ ) : Endapan

Tabel 2. Hasil analisis kuantitatif kadar timbal $(\mathrm{Pb})$ pada larutan sampel secara spektrofotometri serapan atom (SSA) pada panjang gelombang 217,0 nm

\begin{tabular}{ccccc}
\hline Replikasi & $\begin{array}{c}\text { Berat sampel } \\
(\mathbf{g r a m})\end{array}$ & Serapan $(\mathbf{A})$ & $\begin{array}{c}\text { Konsentrasi Timbal } \\
(\mathbf{b p j})\end{array}$ & $\begin{array}{c}\text { Konsentrasi rata-rata } \\
(\mathbf{b p j})\end{array}$ \\
\hline I & 10,0147 & 0,0142 & 0,764 & \\
II & 10,0147 & 0,0142 & 0,769 & 0,7636 \\
III & 10,0147 & 0,0141 & 0,758 & \\
\hline
\end{tabular}

Keterangan : Volume sampel $=50 \mathrm{ml}$ 
Tabel 3. Hasil analisis kuantitatif kadar kadmium (Cd) pada larutan sampel secara spektrofotometri serapan atom (SSA) pada panjang gelombang 228,8 nm.

\begin{tabular}{ccccc}
\hline Replikasi & $\begin{array}{c}\text { Berat sampel } \\
\text { (gram) }\end{array}$ & Serapan (A) & $\begin{array}{c}\text { Konsentrasi Cadmium } \\
(\mathbf{b p j})\end{array}$ & $\begin{array}{c}\text { Konsentrasi rata-rata } \\
(\mathbf{b p j})\end{array}$ \\
\hline I & 10,0147 & 0,0448 & 0,4748 & \\
II & 10,0147 & 0,0455 & 0,4843 & 0,4730 \\
III & 10,0147 & 0,0437 & 0,4598 & \\
\hline
\end{tabular}

Keterangan : Volume sampel $=50 \mathrm{ml}$

\section{PEMBAHASAN}

Pada penelitian ini dilakukan analisis kandungan logam timbal dan kadmium pada udang windu yang di ambil dari perairan Beniung Tarakan di Kalimantan Timur

Sampel yang diteliti didekstruksi dengan pemijaran pada suhu $550^{\circ} \mathrm{C}$. Dekstruksi merupakan suatu cara untuk menghilangkan senyawasenyawa yang ada di dalam sampel. Kemudian penambahan asam klorida pada abu yang diperoleh dari hasil pemijaran digunakan sebagai pelarut. Kelebuhan asam dihilangkan dengan cara diuapkan dengan pemanasan kembali. Abu yang diperoleh dilarutkan dengan asam nitrat, dimaksudkan untuk menyempurnakan hilangnya senyawa-senyawa organik yang berada di dalam sampel lalu dipanaskan kembali, kemudian dicukupkan volumenya dengan aquades dalam labu tentukur $50 \mathrm{ml}$. Larutan sampel yang diperoleh, dianalisis secara kualitatif dan kuantitatif. Pada analisis kualitatif dilakukan identifikasi logam Pb dan Cd dengan menambahkan larutan kalium iodida pada tabung reaksi yang berisi larutan sampel, dimana menghasilkan endapan kuning yang menandakan adanya logam timbal $(\mathrm{Pb})$ dan pada penambahan natrium karbonat positif menghasilkan endapan putih yang menandakan adanya logam timbal (Pb). Sedangkan pada logam kadmium (Cd) diidentifikasi dengan penambahan larutan hydrogen sulfida, menghasilkan warna kuning dan membentuk endapan begitu juga pada penambahan natrium hidroksida positif menghasilkan endapan putih yang menandakan adanya logam kadmium (Cd) dalam larutan sampel. Pada analisa secara kuantitatif dilakukan dengan metode Spektrofotometri Serapan Atom (SSA).

Hasil penelitian diperoleh kadar logam timbal dalam udang windu 
(Penaeus monodon) rata-rata yaitu 0,7636 bpj. Kandungan logam timbal ini tidak melebihi ambang batas pada lampiran surat keputusan Direktorat Jenderal Pengawasan Obat dan Makanan (DIRJEN POM) NO.03725/B/SK/VII/89 yaitu 2,0 bpj. Sedangkan kadar logam kadmium yang terdapat pada udang windu adalah 0,4730 bpj. Kandungan logam kadmium pada bahan pangan lampiran surat keputusan DIRJEN POM NO.03725/B/SK/VII/89 yaitu 1,0 bpj, hal ini menunjukkan bahwa udang windu yang berasal dari perairan Beniung Tarakan Kalimantan timur tidak melebihi ambang batas dari ketetapan yang ada.

\section{KESIMPULAN}

Berdasarkan penelitian yang dilakukan maka diperoleh hasil yaitu kadar logam timbal pada udang windu adalah 0,7636 bpj dan untuk kandungan logam kadmium adalah 0,4730 bpj.

\section{DAFTAR PUSTAKA}

Alastair, S., 2001, Material, diterjemahkan Athanasius, Pakar Raya, Bandung.

Badan Standardisasi Nasional. SNI 7387-2006. Batas Maksimum Cemaran Logam Berat Dalam Pangan. pphp.deptan.go.id. Diakses 14 Mei 2010
Binaraga, 2009. Udang, Kaya Protein dan Rendah Kalori. http://www. binaraga.net. Diakses 10 April 2009

Ciptakarya.pu.go.id/ Profil Kabupaten/Kota Tarakan. Pdf. Diakses 10 April 2009.

Darmono, 1995, Logam dalam Sistem Biologi Makhluk Hidup, UIPress, Jakarta.

Day, Jr, R.A., and Underwood, A.L., 1994, Analisis Instrument Kualitatif, Edisi V., Erlangga, Jakarta.

Gandjar, I.G., dan Rohman, Abdul., 2008, Kimia Farmasi Analisis, Pustaka Pelajar, Yogyakarta.

Harmita, 2006, Analisis kuantitatif Bahan baku dan sediaan Farmasi, Departemen Farmasi MIPA Universitas Indonesia, Jakarta.

Khopkar, S.M., 1990. Konsep Dasar Kimia Analitik, diterjemahkan Saptoraharjo, Universitas Indonesia Press, Jakarta.

Massofa.wordpress.com/2008/06/23/P eluang dan Tantangan Pengolahan SDA Kelautan dan Pesisir di KotaTarakan. Diakses 10 April 2009.

Minda.

Blogspot.com/2009/04/tumpaha n-minyak. Diakses 7 Februari 2010.

Mulja, M., dan Suharman, 1995, Analisis Instrumental, Penerbit Universitas Airlangga, Surabaya. 
Murtidjo, B. A., 2003, Benih Udang Windu Skala Kecil, Kanisius, jakarta.

Padangkini,www. Padangk ini._Com /berita /single.php

Palar, H., 2008, Pencemaran dan Toksikologi Logam Berat, Penerbit Rineka Cipta, Jakarta.

Suyanto, S., dan Mujiman, 2005, Budidaya Udang Windu. Penebar Swadaya, Jakarta.
Sumeru, 1999, Teknik Budidaya Udang Windu, Sinar Baru. Bandung.

Syahid, M., Subhan, Ali., dan Armando, R., 2006, Udang Windu (online) http://hobiikan.blogspot.com/2 008/08/udang-windu.html. Diakses 2 Maret 2009.

Widyastuti, P., 2006, Bahaya Bahan Kimia pada Kesehatan Manusia dan Lingkungan, Penerbit Buku Kedokteran, Jakarta. 